\title{
Analiza antropologiczna materiału kostnego podjętego w czasie badań ratowniczych na Placu Słowiańskim w Krakowie (sezon 2017)
}

\author{
Justyna Marchewka \\ Zakład Biologii Człowieka, Wydział Biologii i Nauk o Środowisku \\ Uniwersytet Kardynała Stefana Wyszyńskiego w Warszawie, ul. Wóycickiego 1/3, 01-938 Warszawa \\ j.marchewka@uksw.edu.pl
}

\begin{abstract}
Streszczenie
Celem pracy było oszacowanie najmniejszej możliwej liczby pochowanych (MNI) w analizowanym ossuarium podjętym w czasie prac ratowniczych na krakowskim Placu Słowiańskim. Prócz tego podjęto próbę określenia profilu biologicznego zmarłych oraz próbę ustalenia, z którego z przykościelnych cmentarzy zlokalizowanych przy Placu Słowiańskim mogły one pochodzić.

MNI zostało ustalone w oparciu o zachowane kości skroniowe strony prawej i wyniosło 51. Najliczniej reprezentowanymi w badanym materiale kośćmi były kości czaszki i większe kości szkieletu postkranialnego. Zauważono także zdecydowanie mniejszy udział kości dziecięcych. Obie te obserwacje wskakują na selekcję kości jakiej dokonywano w czasie przenosin szkieletów grobów pierwotnych do grobu wtórnego. Wyniki badań nie pozwoliły na jednoznaczne wskazanie pochodzenia szczątków, choć bardziej prawdopodobnym jest, iż ossuarium powstało na skutek przenosin ciał z cmentarza przy kościele św. Krzyża.
\end{abstract}

\section{Slowa kluczowe}

analiza antropologiczna, ludzkie szczątki kostne, ossuarium

\section{Wstęp}

W czasie prac ratowniczych prowadzonych w roku 2017 przy obecnym Placu Słowiańskim, podjęto znaczną liczbę materiału osteologicznego pochodzącego głównie z ossuarium. Tego rodzaju obiekty stanowią specyficzny rodzaj pochówków zbiorowych, które zawierają liczne, bardzo często selektywnie wybierane elementy szkieletu (Szczepanek 2013: 12). Powstają najczęściej wskutek przenoszenia szkieletów z pochówków pierwotnych do wspólnej jamy grobowej, w związku z tym w ossuariach rejestrowana jest najczęściej obecność czaszek i większych kości szkieletu postkranialnego (np. kości udowych czy piszczelowych), ponieważ jego mniejsze elementy pozostawały w miejscu pierwotnego złożenia ciała (Szczepanek 2013: 15). Jak zauważa Szczepanek (2013) analiza antropologiczna tego typu pochówków wymaga w pierwszej kolejności starannej segregacji materiałów i w przypadkach, kiedy to możliwe, rekonstrukcji kości. W następnej kolejności konieczne jest ustalenie minimalnej liczby osobników (MNI Minimal Number of Individuals), których 
szczątki złożono w grobie wtórnym. Dopiero potem, w oparciu o zachowane elementy szkieletu możliwa jest próba rekonstrukcji profilu biologicznego zmarłych, oczywiście istotnym elementem jest dobranie odpowiednich ku temu metod badawczych.

Plac Słowiański w Krakowie leży w obrębie Kleparza. Początek osadnictwa na tym terenie związany jest $\mathrm{z}$ ufundowaniem przez biskupa Gedkę kościoła św. Floriana (rok 1184). Lokacja miasta Kleparz na prawie magdeburskim miała miejsce w 1366 roku, jednak w związku z tym, że Kleparz nie miał możliwości rozwoju terytorialnego, a jego gospodarka była uzależniona od Krakowa, funkcjonował on bardziej jako część rozległych suburbiów Krakowa, aniżeli odrębne miasto. Ostatecznie Kleparz został włączony w granice administracyjne Krakowa w 1792 roku, a prawa miejskie utracił w 1794 roku. Na terenie Kleparza rozwinęło się rzemiosło, głównie tkactwo, garbarstwo, kowalstwo, rymarstwo, na terenie miasta funkcjonowała także znaczna liczba oberż i zajazdów dla podróżnych (Leśniak 2003: 148; Krzysztofik 2007: 38-39). Przy obecnym Placu Słowiańskim do początków XIX wieku funkcjonowały dwa, nieistniejące dziś, kościoły z niewielkimi cmentarzami. Pierwszym z nich był Kościół św. Krzyża, nazywany także kościołem słowiańskim. Został on ufundowany przez Władysława Jagiełłę i Jadwigę w 1390 roku, z myślą o benedyktynach obrządku słowiańskiego. Akta wizytacji biskupiej z 1599 r. zawierają opis kościoła jako murowanej, choć zaniedbanej kaplicy z czterema oknami i ołtarzem. Wokół kościoła miał znajdować się nieduży, nieogrodzony cmentarz. Kościół był wielokrotnie niszczony przez pożary i odbudowywany, po wejściu do miasta Austriaków został przekształcony na magazyn zboża, a w 1808 roku podjęto decyzję o jego rozbiórce (Kęder, Kęder 2000: 450-451; Beiersdorf 2007: 427-454). Obecnie o istnieniu w tym miejscu świątyni przypomina tablica pamiątkowa i nazwa ulicy Słowiańskiej. Drugim z kościołów funkcjonujących przy Palcu Słowiańskim był kościół św. Walentego.
Miał on powstać w 1441 lub 1447 roku, przy funkcjonującym od XIV wieku szpitalu dla trędowatych pod wezwaniem św. Walentego. Przy kościele miał funkcjonować cmentarz dla trędowatych. Zgodnie z opisem biskupa Radziwiłła z 1599 roku, była to drewniana kaplica z ceglaną posadzką i trzema wyjściami. Do kościoła miał przylegać dom, którego murowany parter przeznaczony był na leprozorium, nieopodal kościoła miał znajdować się kolejny budynek szpitalny. Po licznych pożarach i odbudowach, zaniedbany kościół zburzono w 1818 roku, a znajdującą się na cmentarzu latarnię umarłych przeniesiono pod kościół św. Mikołaja przy obecnej ulicy Kopernika (Rożek 1983: 95-120; Kęder, Kęder 200o: 450-451; Myszka 2003: 121-143). Usytuowanie kościołów św. Krzyża i św. Walentego względem siebie zamieszczono na rycinie 1.

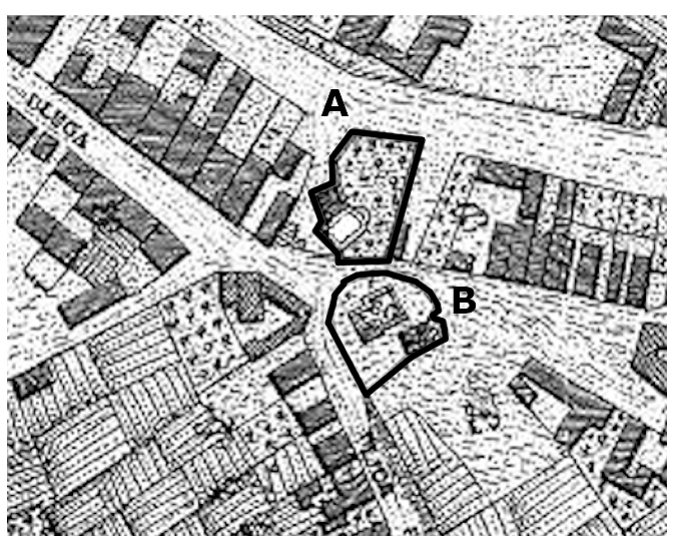

Ryc. 1. Lokalizacja kościołów św. Krzyża

(A) i św. Walentego (B) wraz z przyległymi cmentarzami na Planie Kołłątajowskim z 1785 r.

Jak wynika z zamieszczonego planu kościoły wraz z cmentarzami znajdowały się w bardzo bliskim sąsiedztwie, w związku z powyższym, z archeologicznego punktu widzenia, istotnym celem analizy antropologicznej była próba ustalenia, z którego z cmentarzy przykościelnych pochodził materiał kostny zdeponowany w badanym ossuarium. Nadrzędnym celem podjętych badań antropologicznych było oszacowanie minimalnej liczby osób (MNI), których szczątki 
złożono w badanym ossuarium oraz próba określenia ich profilu biologicznego.

\section{Materiał i metody}

Materiał kostny został podjęty, w czasie ratowniczych prac wykopaliskowych, prowadzonych na terenie dzisiejszego Placu Słowiańskiego w Krakowie i został wydatowany na przełom XVII i XVIII wieku. Zdecydowana większość badanych kości nosiła ślady uszkodzeń post mortem, z których znaczna część powstała najprawdopodobniej w wyniku przenoszenia szkieletów z miejsc pierwotnego pochówku do wspólnej jamy grobowej. W pierwszej kolejności materiał został oczyszczony, oddzielono od kości ludzkich kości zwierzęce. Następnie, kości ludzkie zostały posegregowane i zgodnie z powszechnie wykorzystywaną metodyką badawczą określona została Minimalna Liczba Osobników (MNI - Minimal Number of Individuals). Zastosowano metodykę zaproponowaną przez White'a (1953), standardowo wykorzystywaną w badaniach antropologicznych i zooarcheologicznych (Buikstra, Ubelaker 1994: 9; Lyman 20o8: 38-82; Szczepanek 2013: 19). Przyjęto, że w obiektach, które charakteryzuje znaczny stopień przemieszania i rozproszenia materiału kostnego, MNI jest wartością szacunkową i zależną od liczby zachowanych elementów diagnostycznych (Szczepanek 2013: 91). Ocena płci badanych osobników została wykonana w oparciu o powszechnie stosowane w antropologii fizycznej metody (Bukistra, Ubeleker 1994). Wykorzystano również metody oparte o pomiary wykonywane na kościach długich między innymi średnice głów kości ramiennej i udowej (Bass 1995). Oceniając wiek w chwili śmierci także wykorzystano powszechnie używaną metodykę (Bukistra, Ubelaker (1994). Występowanie w badanej serii zmian o charakterze patologicznym oceniono makroskopowo i klasyfikowano zgodnie z powszechnie wykorzystywanym w antropologii systemem ich podziału (Ortner 2003). Ze względu na fakt, iż badany materiał mógł pochodzić z cmentarza przy kościele św. Walentego baczną uwagę zwracano na obecność zmian, które w obrazie makroskopowym mogą wskazywać, na występowanie zmian potrądowych.

W przypadku kompletnie zachowanych kości udowych strony prawej wykonano rekonstrukcję przyżyciowej wysokości ciała. Wykorzystano kość udową, ponieważ to jej długość najsilniej koreluje z ostateczną wysokością ciała (Hauser i in. 2005). Biorąc pod uwagę sugestie Sierp i Henneberga (2016) wykorzystano metodę opracowaną dla najbliższej genetycznie populacji, a taką jest seria współczesnych gdańszczan, dla których metodę rekonstrukcji opracowali właśnie Hauser z zespołem (2005). Aby móc porównać analizowaną serię z innymi równoczasowymi populacjami do oceny wysokości ciała wykorzystano także metodę Trotter i Glesser (1952). Wykonano także rekonstrukcję przyżyciowej masy ciała, w tym celu wykorzystano metodę zaproponowaną przez Ruffa i in. (1991).

\section{Wyniki}

Na podstawie zachowanych elementów czaszki i szkieletu postkranialnego oszacowana została najmniejsza możliwa liczba osobników (MNI), których kości znalazły się w badanym depozycie. Wyniki tej części analizy zostały zebrane w tabeli 1. Najliczniej reprezentowanymi kośćmi w badanym materiale były kości skroniowe strony prawej, których liczba wyniosła 51 i to na podstawie tej liczby została ustalona MNI. Należy zaznaczyć, że poszczególne elementy czaszki liczone były łącznie dla czaszek zachowanych, jak i dla luźnych kości obecnych w materiale. Łączna liczba zachowanych czaszek wyniosła 14, pozostałą część stanowiły luźne elementy tej części szkieletu. Znaczną część materiału stanowiły kości długie, w tym kości ramienne, łokciowe, udowe i piszczelowe. Mniejsze fragmenty szkieletu takie jak kręgi, kości śródręcza, żebra czy paliczki ręki i stopy rejestrowano w badanym materiale zdecydowanie rzadziej. Na rycinie 2 zaprezentowano liczbę zachowanych elementów szkieletu postkranialnego z podziałem na dorosłych i dzieci. Wartym zauważenia jest 
Tabela 1. Oszacowanie najmniejszej możliwej liczby pochowanych w ossuarium

\begin{tabular}{|c|c|c|c|}
\hline \multirow{2}{*}{ Element szkieletu } & \multicolumn{2}{|c|}{ strona } & \multirow{2}{*}{ MNI } \\
\hline & prawa & lewa & \\
\hline kośćc czołowa & \multicolumn{2}{|c|}{49} & 49 \\
\hline żuchwa & \multicolumn{2}{|c|}{13} & 13 \\
\hline szczęka & \multicolumn{2}{|c|}{21} & 21 \\
\hline kość potyliczna & \multicolumn{2}{|c|}{27} & 27 \\
\hline kość skroniowa & 51 & 46 & 51 \\
\hline kość jarzmowa & 8 & 6 & 8 \\
\hline łopatka & 10 & 13 & 13 \\
\hline obojczyk & 26 & 31 & 31 \\
\hline kość ramienna & 38 & 29 & 38 \\
\hline kość promieniowa & 18 & 16 & 18 \\
\hline kość łokciowa & 27 & 28 & 28 \\
\hline I kość śródręcza & 12 & 18 & 18 \\
\hline miednica & 26 & 20 & 26 \\
\hline kość udowa & 31 & 33 & 33 \\
\hline kość piszczelowa & 30 & 35 & 35 \\
\hline kość strzałkowa & 15 & 12 & 15 \\
\hline kość piętowa & 23 & 24 & 24 \\
\hline kość skokowa & 20 & 18 & 20 \\
\hline I kość śródstopia & 18 & 22 & 22 \\
\hline kość krzyżowa & & & 15 \\
\hline
\end{tabular}

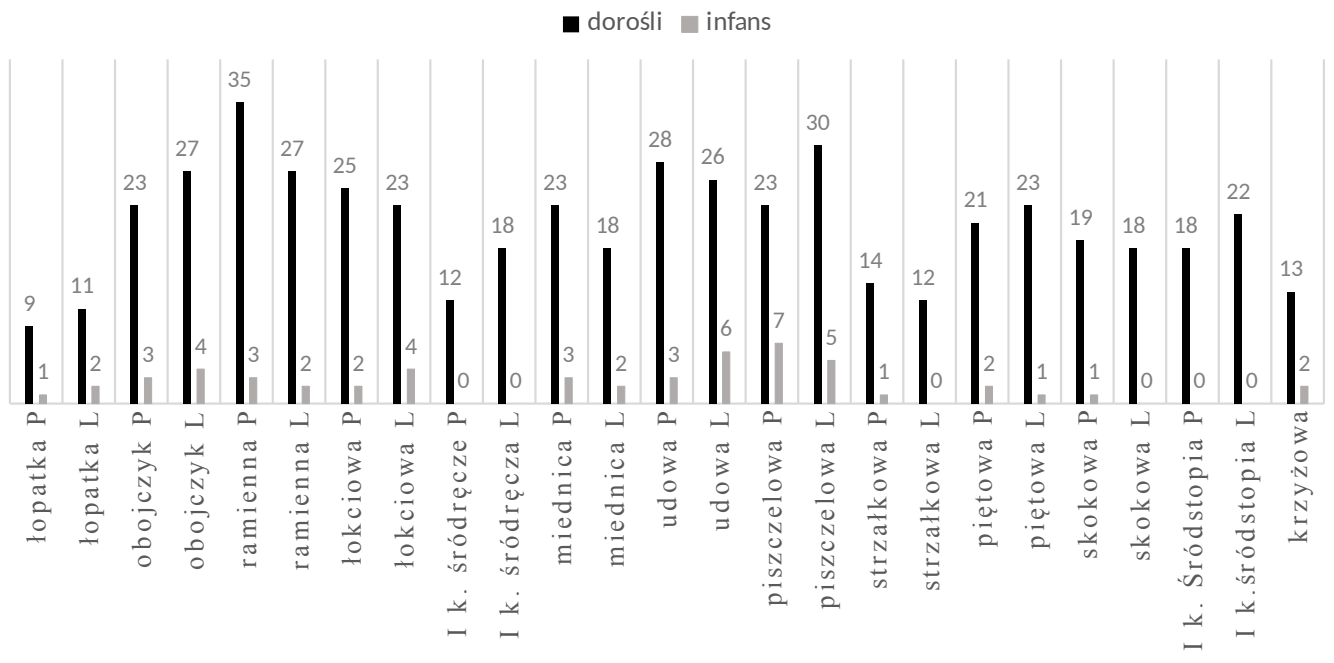

Ryc.2. Liczba zachowanych elementów szkieletu postkranialnego u dorosłych i dzieci 
zdecydowana dysproporcja między liczebnością kości należących do osób dorosłych i kości dziecięcych. Mniejsza liczebność niewielkich rozmiarowo partii szkieletu oraz znaczna różnica w liczbie kości dorosłych i dzieci może wynikać z opisywanej często dla tego typu obiektów selekcji kości. Uznaje się, że w ossuariach powstających na skutek przenosin szkieletów z miejsc i pierwotnego pochówku najczęściej wybierano kości szkieletu postkranialnego o znacznych rozmiarach i czaszki. Na rycinie 2 można zauważyć, że w przypadku elementów czaszki zachowanych jest znacznie więcej fragmentów należących do osobników niedorosłych.

W kolejnym etapie analizy antropologicznej, której celem było określenie płci i wieku w chwili śmierci, poddano zachowane czaszki, następnie żuchwy i fragmenty szczęk. Zdecydowana większość z nich to czaszki, których stan opisano jako Calvaria
( 8 z badanych czaszek), w następnej kolejności Calotta (3 czaszki) i wreszcie Calvarium (2 czaszki). Należały one do osobników dorosłych. W tabeli 2 zaprezentowano rozkład liczby czaszek w zależności od płci i wieku w chwili śmierci.

Rekonstrukcja przyżyciowej wysokości i masy ciała została wykonana dla kompletnie zachowanych kości strony lewej, ponieważ liczba kompletnie zachowanych kości tej strony była większa i wyniosła 7 . W oparciu o średnicę głowy i morfologię kości podzielono je na kości męskie i żeńskie. Średnie wartości długości M1 kości oraz średnic głów wraz ze zrekonstruowaną przyżyciową wysokością i masą ciała zamieszczono w tabeli 3 .

Jednym z celów prowadzonych badań była próba ustalenia, $\mathrm{z}$ którego $\mathrm{z}$ badanych cmentarzy przykościelnych pochodzą złożone w ossuarium części szkieletów. W badanym

Tabela 2. Liczba zachowanych w materiale czaszek w zależności od płci i wieku w chwili śmierci

\begin{tabular}{lccccc}
\hline & \multicolumn{4}{c}{ Płeć } \\
\cline { 2 - 6 } Kategoria wiekowa & M & M? & K & K? & $?$ \\
\hline adultus & 3 & 2 & 0 & 0 & 0 \\
adultus/maturus & 0 & 0 & 1 & 1 & 0 \\
maturus & 0 & 0 & 1 & 0 & 0 \\
maturus/senilis & 1 & 0 & 0 & 0 & 1 \\
senilis & 1 & 1 & 0 & 1 & 0 \\
Łącznie & 5 & 3 & 2 & 2 & 1 \\
\hline
\end{tabular}

Tabela 3. Zrekonstruowana przyżyciowa wysokość i masa ciała dla kompletnie zachowanych kości udowych

\begin{tabular}{|c|c|c|c|c|c|c|}
\hline & \multirow[b]{2}{*}{ Płeć } & \multirow[b]{2}{*}{ M1 } & \multirow[b]{2}{*}{ Śr. głowy } & \multicolumn{2}{|c|}{ Wysokośćciała } & \multirow{2}{*}{$\begin{array}{c}\text { Masa ciała } \\
\text { Ruff } \mathrm{i} \text { in. (1991 }\end{array}$} \\
\hline & & & & Trotter i Glesser (1952) & Hauser i in. (2005) & \\
\hline 1 & K & 400 & 43 & 152,9 & 154,5 & 62,3 \\
\hline 2 & K & 422 & 40 & 158,3 & 159,8 & 55,4 \\
\hline 3 & K & 401 & 43 & 153,1 & 154,7 & 62,3 \\
\hline \multicolumn{4}{|c|}{ Średnia dla kości żeńskich } & 154,8 & 156,3 & 60,0 \\
\hline 4 & M & 426 & 46 & 165,5 & 161,2 & 64,1 \\
\hline 5 & M & 461 & 48 & 173,8 & 171,3 & 69,0 \\
\hline 6 & M & 415 & 47 & 162,9 & 158,1 & 66,5 \\
\hline 7 & M & 434 & 48 & 167,4 & 163,5 & 69,0 \\
\hline \multicolumn{4}{|c|}{ Średnia dla kości męskich } & 167,4 & 163,5 & 67,1 \\
\hline
\end{tabular}




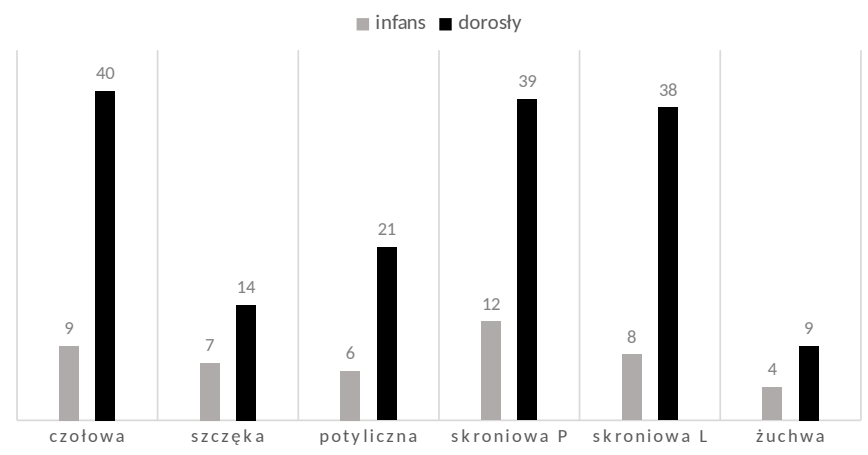

Ryc.3. Liczba zachowanych elementów czaszek z podziałem na dorosłych i dzieci

materiale obserwowano przede wszystkim obecność uszkodzeń post mortem. Wygładzenie krawędzi przełomów i ich kolor wskazują, że były to uszkodzenia powstałe najprawdopodobniej w czasie przenoszenia elementów szkieletów z grobów pierwotnych do grobu wtórnego. Prócz tych zmian obserwowano także występowanie śladów schorzeń i urazów powstałych przyżyciowo. Jednym z przykładów zmian przyżyciowych i peri mortem jest czaszka oznaczona numerem 2, należąca do osobnika, którego płeć oznaczono jako prawdopodobnie męską. Stopień obliteracji szwów czaszkowych wskazuje, że był to człowiek zmarły przed 30 rokiem życia. Na czaszce zarejestrowano trzy zmiany zaprezentowane na rycinie 4. Pierwszy z urazów ante mortem zlokalizowany jest na łusce lewej kości ciemieniowej, w jej środkowej części poniżej guza ciemieniowego. Tylna krawędź zmiany znajduje się 2,5 cm od szwu węgłowego. Długość zmiany wynosi 4,1 cm, ma lekko zaokrąglony kształt, wykazuje ślady wygojenia (ryc. 4a). Druga ze zmian ante mortem znajduje się na prawej kości ciemieniowej w okolicy szwu wieńcowego i ma postać okrągłego wklęśnięcia z widocznymi śladami delikatnego procesu zapalnego. Średnica wklęśnięcia wynosi 1,6 cm (ryc. 4b). Uraz, który najprawdopodobniej powstał w okolicy śmierci znajduje się w centralnej części łuski kości czołowej po stronie lewej. Ma owalny kształt o wymiarach 1,3 × 1,o cm. Wokół zagłębienia znajdują się koncentryczne pęknięcia kości i to właśnie ich obecność wskazuje na to, że uraz powstał peri mortem.

W zachowanym materiale zarejestrowano także występowanie osteomy, czyli łagodnego nowotworu tkanki kostnej. Jego obecność zarejestrowano w dwóch przypadkach, pierwszym z nich była czaszka oznaczona jako 6. Należała ona do kobiety zmarłej między 35 a 45 rokiem życia, a osteoma zlokalizowana była w tylnej części prawej kości ciemieniowej w okolicy punktu lambda (ryc. 5a). Drugim przypadkiem była częściowo zniszczona kość czołowa osobnika dorosłego. Nowotwór znajdował się we wnętrzu lewej zatoki czołowej (ryc. 5b).

W materiale odnaleziono także nieliczne kości, na których zaobserwowano występowanie śladów zmian zapalnych typu osteomyelitis, których obraz morfologiczny może wskazywać, że są to zmiany potrądowe. Do kości tych należały dwie kości piszczelowe (prawa i lewa), prawa kość udowa i prawa kość strzałkowa. Obraz morfologiczny tych zmian został przedstawiony na rycinie 6. Należy jednak podkreślić, że tego typu zmiany mają charakter nieswoisty co oznacza, że potwierdzenie występowania trądu musi zostać potwierdzone badaniami DNA.

\section{Dyskusja}

Analiza antropologiczna materiałów podejmowanych z grobów wtórnych wymaga ścisłej współpracy antropologa i archeologa, co jest niezwykle istotne przy interpretacji przeznaczenia i funkcjonowania 

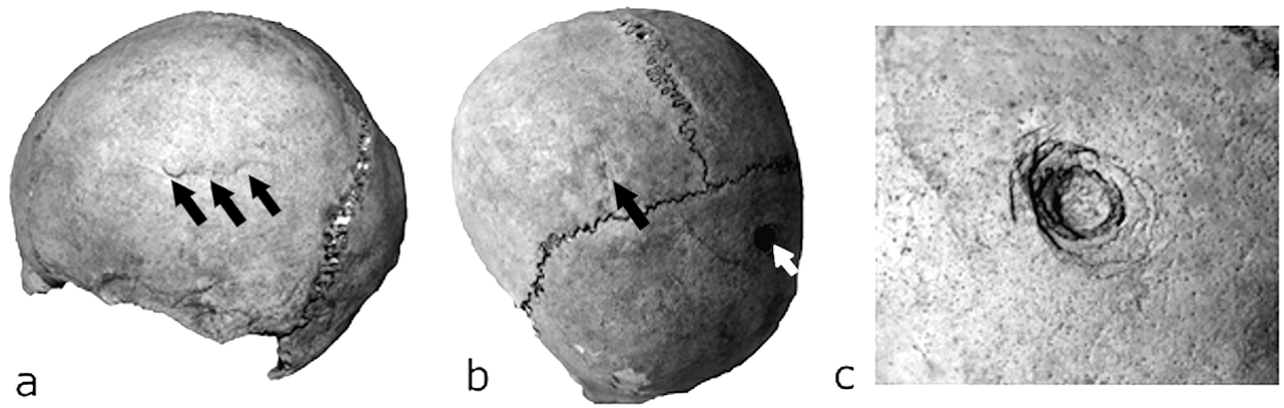

Ryc. 4. Urazy zarejestrowane na czaszce nr 2 (M?, wiek w chwili śmierci adultus); a - zmiana przyżyciowa na lewej kości ciemieniowej (czarne strzałki); b - czarną strzałką wskazano uraz przyżyciowy, białą strzałką uraz powstały prawdopodobnie $\mathrm{w}$ okolicy śmierci; $\mathrm{c}$ - widok na uraz peri mortem (oznaczony na rycinie b białą strzałką)
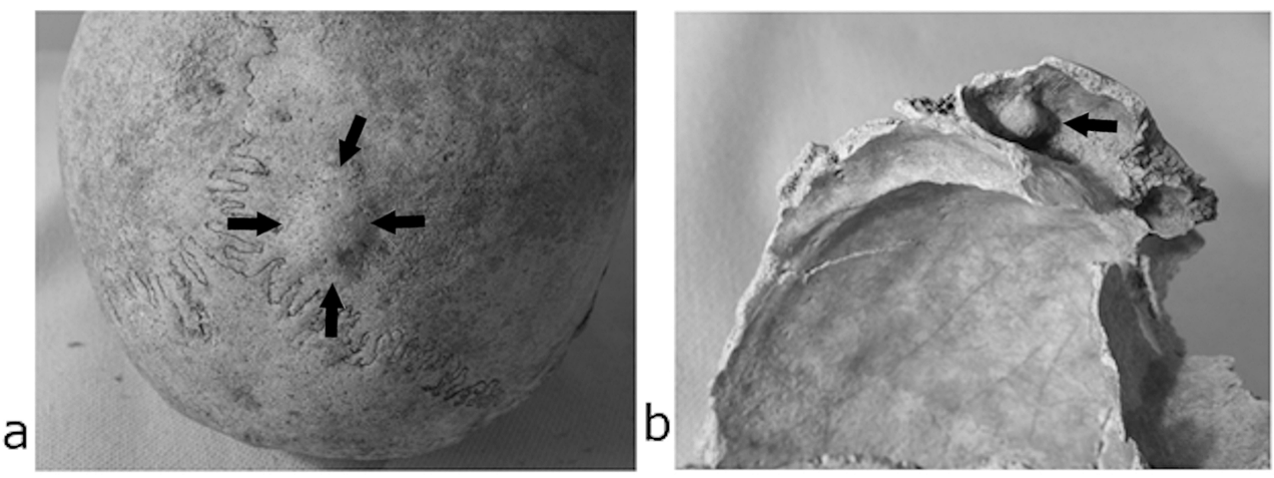

Ryc. 5. Przypadki osteomy: a - czaszka kobieca, wiek w chwili śmierci 35-35 lat; b - lewa zatoka czołowa, osobnik dorosły

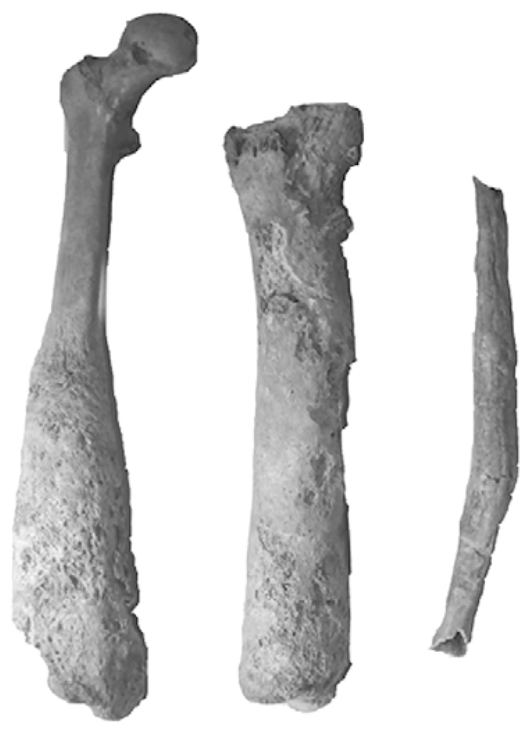

Ryc. 6. Zmiany zapalne na trzonach kości udowej (z lewej), piszczeli (środkowa) i kości strzałkowej analizowanego obiektu (Szczepanek 2013: 109). W przypadku omawianego ossuarium z Placu Słowiańskiego w Krakowie, przyjęto, iż obiekt powstał w czasie przenosin jednego z przyległych do Placu kościołów, mianowicie kościoła św. Krzyża lub kościoła św. Walentego. Zgodnie z dostępnymi źródłami historycznymi kościół św. Walentego funkcjonował przy szpitalu dla chorych na trąd. W związku z tym obecność w materiale zmian typowych dla choroby Hansena wskazywałaby na to, że materiał kostny zdeponowany w badanym ossuarium pochodziłby z cmentarza przy tym kościele. Ponieważ $\mathrm{w}$ analizowanym materiale, który charakteryzował się znacznym przemieszaniem i fragmentacją materiału, prócz czterech kości ze zmianami typu osteomyelitis, nie stwierdzono innych typowych dla trądu 
zmian na kościach należy uznać, że szczątki te pochodziły raczej z cmentarza przy kościele św. Krzyża. Niemniej rozstrzygającym w tym przypadku będzie wynik badań genetycznych.

W badanym materiale zaobserwowano zdecydowaną przewagę kości czaszki i dużych kości szkieletu postkranialnego, co jest zjawiskiem typowym dla pochówków wtórnych (Szczepanek 2013; 109). Należy zaznaczyć, że badany obiekt powstał najprawdopodobniej na skutek symbolicznego przenoszenia szczątków związanego z przenosinami cmentarza lub porządkowaniem jego ograniczonej przestrzeni tak aby możliwe było chowanie kolejnych zmarłych. Obecność w ossuarium głównie elementów czaszek i kości szkieletu postkranialnego o znacznych rozmiarach, a także niewielki udział osobników niedorosłych wskazuje, na to, że w czasie przenoszenia szczątków z miejsc pierwotnego pochówku dokonywano selekcji. Wybierano głównie czaszki osobników dorosłych i ich kości długie, a także elementy czaszek dzieci. Mniejsze kości szkieletu postkranialnego i drobne kości dziecięce najprawdopodobniej pozostawiano w miejscu pochówku pierwotnego. Warto zauważyć, iż taki stan rzeczy znacząco wpływa nie tylko na ostateczną jakość analizy antropologicznej, ale także na zasadniczą kwestię związaną z ustaleniem liczby pochowanych w ossuariach. Dodatkowym czynnikiem wpływającym na wyniki analizy antropologicznej jest także stopień fragmentacji materiału szkieletowego (Szczepanek 2013; 95).

Zrekonstruowana przyżyciowa wysokość i masa ciała odtworzona na podstawie lewej kości udowej nie odbiega od zakresu zmienności typowego dla równoczasowych serii szkieletowych, w tym także od wyników uzyskiwanych w innych obiektach tego typu (Marchewka, Pudło 2017; 210). Analogicznie jak w przypadku ossuariów przy Placu dominikańskim w Gdańsku (Budnik, Pudło 2017 ; 141) oraz obiektów analizowanych przez Szczepanek (2013) w badanych materiałach obserwowano głównie kości osób dorosłych, co jak już wspomniano wynika najprawdopodobniej z selekcji prowadzonej w czasie przenoszenia szkieletów. W przypadku zachowanych czaszek zaobserwowano nieznaczną przewagę osobników płci męskiej i prawdopodobnie męskiej oraz fakt, że osobnicy ci zmarli we wcześniejszych etapach życia (kategoria wiekowa adultus).

\section{Bibliografia}

Bass W.M., 1995, Human Osteology: A Laboratory and Field Manual, 4th edition. Columbia, Missouri: Missouri Archaeological Society.

Biersdorf Z., 2007, Kleparz, w: Wyrozumski J (red.), Kraków. Nowe studia nad rozwojem miasta, Biblioteka Krakowska 150, 427-454.

Budnik A., Pudło A., 2017, Biodemografia nowożytnego Gdańska w świetle badań nad ossuariami. Możliwości rekonstrukcji i problemy metodyczne, w: red: Pudło A., Henneberg M. (red.), Nowożytne ossuaria z klasztoru dominikańskiego w Gdańsku. Wyniki badań interdyscyplinarnych. Fontes Commentationesque ad Res Gestas Gedani et Pomeraniae 6, 141-171.

Buikstra J.E., Ubelaker D.H., 1994, Standards for data collection from human skeletal remains. Arkansas Archeological Survey Research Series No. 44: Fayetteville.

Hauser R., Smoliński J., Gos T., 2005, The estimation of stature on the basis of measurements of the femur. Forensic Science International 147(2-3), 185-190.

Kęder I., Kęder W., 20oo, Kościoły nieistniejące, w: Encyklopedia Krakowa, Warszawa-Kraków, 450-451.

Krzysztofik R., 2007, Lokacje miejskie na obszarze Polski. Dokumentacja geograficzno-historyczna, Katowice, 38-39.

Leśniak F., 2003, Król i jego miasta w województwie krakowskim (od wieku XVI do pierwszej połowy XVIII), w: Dwór a kraj. Między centrum a peryferiami władzy, Kraków, 148.

Lyman R.L., 20o8, Quantitative Paleozoology. Cambridge University Press, Cambridge.

Marchewka J., Pudło A., 2017, Wysokość i masa ciała mieszkańców Gdańska w XV-XVIII wieku. w: red: Pudło A., Henneberg M. (red.), Nowożytne ossuaria z klasztoru dominikańskiego w Gdańsku. Wyniki badań interdyscyplinarnych. Fontes 
Commentationesque ad Res Gestas Gedani et Pomeraniae 6, 210-240.

Myszka M., 2003, Dawne cmentarze Krakowa w świetle badań archeologicznych, w: Cmentarz Rakowicki w Krakowie, Krakowska Teka Konserwatorska, t. III, Kraków, 121-143.

Ortner D.J., 2003, Identification of Pathological Conditions in Human Skeletal Remains, Second Edition. Amsterdam: Academic Press.

Rożek M., 1983, Nieistniejące kościoły Krakowa, Biuletyn Biblioteki Jagiellońskiej 33, 95-120.

Ruff C.B., Scott W.W., Liu A.Y., 1991, Articular and diaphyseal remodeling of the proximal femur with changes in body mass in adults. American Journal of Physical Anthropology 86(3), 397-413.
Sierp I., Henneberg M., 2016, Reconstruction of body height from the skeleton: Testing a dozen different methods for consistency of their results. Antropologischer Anzeiger 73(1), 7-21.

Szczepanek A., 2013, Archeotanatologia pochówków zbiorowych od pradziejów po czasy współczesne. Collectio Archaeologica Ressoviensis 25, Rzeszów.

Trotter M., Gleser G.C., 1952, Estimation of stature from long bones of American Whites and Negroes. American Journal of Physical Anthropology 10(4), 463-514.

White T.E., 1953, A method of calculating the dietary percentage of various food animals utilized by aboriginal peoples. American Antiquity 18(4), 396-398.

\title{
Anthropological analysis of skeletal material taken during rescue investigations at Plac Słowiański in Krakow (2017 season)
}

\begin{abstract}
The aim of the anthropological analysis was to estimate the Minimal Number of Individuals (MNI) in the examined ossuary taken during the rescue work at Plac Słowiański (Krakow). In addition, an attempt was made to determine the biological profile of the deceased and determine from which church cemeteries located near Plac Słowiański they could have originated. MNI was established based on preserved right temporal bones and amounted to 51. The most numerous bones in the examined material were skull bones and larger bones of the post-cranial skeleton. A significantly smaller proportion of children's bones was also noted. Both of these observations jump on the bone selection that was made during the transfer of the skeletons of the primary graves to the secondary grave. The results of the research did not allow for an unequivocal indication of the origin of the remains, although it is more likely that the ossuary was created as a result of the transfer of bodies from the cemetery of the st. Krzyż Church.
\end{abstract}

\section{Keywords}

anthropological analysis, human skeletal remains, ossuary 